\title{
Data report: clay mineral assemblages in slope basin sediments and mass-transport deposits at Sites C0018 and C0021, IODP Expeditions 333 and 338'
}

\author{
Michael B. Underwood ${ }^{2}$
}

\section{Chapter contents}

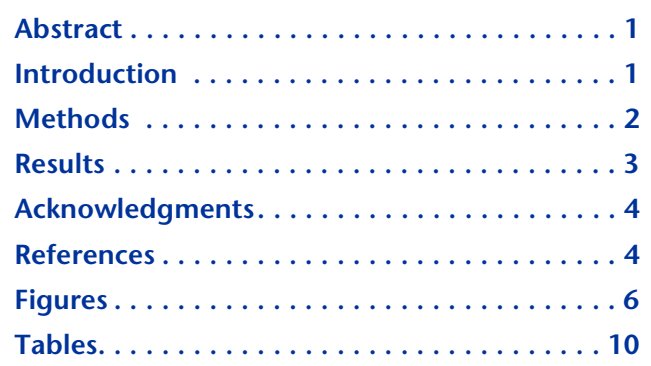

1Underwood, M.B., 2017. Data report: clay mineral assemblages in slope basin sediments and mass-transport deposits at Sites C0018 and C0021, IODP Expeditions 333 and 338. In Strasser, M., Dugan, B., Kanagawa, K., Moore, G.F., Toczko, S., Maeda, L., and the Expedition 338 Scientists, Proceedings of the Integrated Ocean Drilling Program, 338: Yokohama (Integrated Ocean Drilling Program).

doi:10.2204/iodp.proc.338.207.2017

${ }^{2}$ Department of Earth and Environmental Science, New Mexico Institute of Mining and Technology, Socorro New Mexico 87801, USA.

UnderwoodM@missouri.edu

\section{Abstract}

This report summarizes the results of X-ray diffraction analyses of core samples from Sites C0018 and C0021 in the Nankai subduction zone (offshore southwest Japan). The Integrated Ocean Drilling Program recovered the cores during Expeditions 333 and 338 , and a total of 122 specimens were analyzed $(<2 \mathrm{~mm}$ size fraction). Depositional facies include trench slope deposits (hemipelagic mud with thin interbeds of turbidites and volcanic ash), mass-transport deposits (MTD), and sand-rich slope basin deposits. Illite is generally the most abundant clay mineral within both intact and MTD intervals. At Site C0018, the average amount of illite in the clay-size fraction of Subunit Ia (slope basin with MTD) is $37.7 \mathrm{wt} \%$ (standard deviation $=4.2$ ). Proportions of smectite and chlorite average 26.8 and $20.2 \mathrm{wt} \%$, respectively. Average contents of kaolinite and quartz are 4.1 and $11.3 \mathrm{wt} \%$, respectively. Within Subunit Ib (sandy slope basin), the average contents are $37.2 \mathrm{wt} \%$ illite, $23.6 \mathrm{wt} \%$ smectite, $30.7 \mathrm{wt} \%$ undifferentiated chlorite + kaolinite, and $8.5 \mathrm{wt} \%$ quartz. Results are similar at Site C0021, where illite averages $43.7 \mathrm{wt} \%$ (standard deviation $=4.5$ ). Average values for the other minerals are $23.6 \mathrm{wt} \% \mathrm{smec}-$ tite, $24.3 \mathrm{wt} \%$ undifferentiated chlorite + kaolinite, and $8.4 \mathrm{wt} \%$ quartz. Most values of illite/smectite expandability fall between $55 \%$ and $65 \%$. Values of the illite crystallinity index are indicative of detrital sources that were exposed to anchizone and epizone metamorphic conditions.

\section{Introduction}

The Nankai Trough Seismogenic Zone Experiment (NanTroSEIZE) has grown over several years to become the most comprehensive ocean drilling transect in any subduction system (Ashi et al., 2009; Screaton et al., 2009; Tobin et al., 2009; Underwood et al., 2010; Expedition 333 Scientists, 2012a; Tobin et al., 2015; also see the "Expedition 338 summary" chapter [Strasser et al., 2014a]). Expeditions 333 and 338 of the Integrated Ocean Drilling Program (IODP) cored at Sites C0018 and C0021 (Fig. F1). Mass-transport deposits (MTDs) are common at both sites, which are located in a trench-slope basin immediately downslope of a megasplay fault in the accretionary prism (Fig. F2). Site C0021 is located 2 $\mathrm{km}$ northwest of Site C0018 in a more proximal position for the MTDs (Fig. F2). The primary drilling objectives were to establish a 
Quaternary mass-movement event stratigraphy with good age control and to sample an exceptionally thick MTD complex for subsequent analyses of the sediments' rheological behavior.

The dominant lithology at Sites C0018 and C0021 is clayey silt to silty clay (hemipelagic mud). Calcium carbonate contents are relatively high in the mud due to elevation of the slope basin above the calcite compensation depth. Depositional ages, based on nannofossil events and paleomagnetic datums, are younger than $1.46 \mathrm{Ma}$ (Expedition 333 Scientists, 2012b; also see the "Site C0021" chapter [Strasser et al., 2014b]). Thin interbeds of silt- to sand-size volcanic ash are abundant, as are silty to sandy turbidites. A lithologic boundary between Subunits Ia and Ib was recognized based on the prevalence of sand beds (more sand in Subunit Ib). That boundary occurs at 190.65 meters below seafloor (mbsf) at Site C0018 and at 176.17 mbsf at Site C0021 (Fig. F3).

MTDs occur within Subunit Ia. Visual evidence from the split cores for mass-transport mechanisms (e.g., submarine slides and debris flows) includes convolute and tilted strata, intervals of remobilized mud clasts overlying tilted strata, and internal shear zones. Those observations were bolstered by 3-D analyses of X-ray CT scans. The thicker MTD intervals comprise a mixture of mud-rich debrites, intact hemipelagic layers, and convoluted banded deposits denoting extensive deformation within the interior of the failure.

This report documents the results of X-ray diffraction (XRD) analyses of 122 core samples from Sites C0018 and C0021. The report's primary objective is to provide compositional data from the slope basin deposits and MTDs for comparisons with other sites and tectonostratigraphic units along the NanTroSEIZE transect (e.g., Guo and Underwood, 2012; Underwood and Guo, 2013).

\section{Methods}

\section{Sample preparation}

Most of the samples analyzed in this study came from "clusters" that included companion specimens for shipboard bulk-powder XRD, X-ray fluorescence, moisture and density, and carbon-carbonate. The clusters were positioned next to sampling intervals for whole rounds, including those extracted for interstitial water. Shipboard XRD scans provided estimates of the relative abundance of total clay minerals, quartz, feldspar, and calcite (see the "Site C0018" chapter [Expedition 333 Scientists, 2012b], and the "Site C0021" chapter [Strasser et al., 2014b]).

Clay-size fractions were isolated for XRD analyses by air-drying and gentle hand-crushing of the mud with mortar and pestle, after which specimens were immersed in $3 \% \mathrm{H}_{2} \mathrm{O}_{2}$ for at least $24 \mathrm{~h}$ to digest organic matter. To prevent flocculation, $250 \mathrm{~mL}$ of Na-hexametaphosphate solution $(4 \mathrm{~g} / 1000 \mathrm{~mL}$ distilled $\mathrm{H}_{2} \mathrm{O}$ ) was added, and beakers were inserted into an ultrasonic bath for several minutes to promote disaggregation. That step (and additional soaking) was repeated until visual inspection indicated complete disaggregation. Washing consisted of two passes through a centrifuge (8200 rpm for $25 \mathrm{~min}$; 6000 g) with resuspension in distilled deionized water after each pass. After transferring the suspended sediment to a $60 \mathrm{~mL}$ plastic bottle, each specimen was resuspended by vigorous shaking and a 2 min application of an ultrasonic cell probe. A centrifuge was used to separate the clay-size splits $(<2 \mu \mathrm{m}$ equivalent spherical settling diameter; $1000 \mathrm{rpm}$ for $2.4 \mathrm{~min} ; 320 \mathrm{~g}$ ). Preparation of oriented clay aggregates followed the filter-peel method (Moore and Reynolds, 1989) using $0.45 \mu \mathrm{m}$ filter membranes. A closed vapor chamber was used to saturate clay aggregates with ethylene glycol heated to $60^{\circ} \mathrm{C}$ for at least $24 \mathrm{~h}$ prior to XRD analysis.

\section{X-ray diffraction}

Two X-ray diffractometers were used to analyze claysize specimens. When the project began, the XRD laboratory at the University of Missouri was equipped with a Scintag Pad V X-ray diffractometer with $\mathrm{CuK} \alpha$ radiation $(1.54 \AA)$ and Ni filter. Those scans of oriented clay aggregates were run at $40 \mathrm{kV}$ and $30 \mathrm{~mA}$ over a scanning range of $3^{\circ}$ to $26.5^{\circ} 2 \theta$, a rate of $1^{\circ} 2 \theta / \mathrm{min}$, and a step size of $0.01^{\circ} 2 \theta$. Slits were $0.5 \mathrm{~mm}$ (divergence) and $0.2 \mathrm{~mm}$ (receiving). The Department of Geological Sciences shut down that facility before NanTroSEIZE research was finished, so the remaining samples (including all samples from Site C0021) were analyzed at the New Mexico Bureau of Geology and Mineral Resources using a Panalytical X'Pert Pro diffractometer with $\mathrm{Cu}$ anode. We ran those continuous scans at generator settings of $45 \mathrm{kV}$ and $40 \mathrm{~mA}$ over an angular range of $3^{\circ}$ to $26.5^{\circ} 2 \theta$, with scan step time of $1.6 \mathrm{~s}$ and step size of $0.01^{\circ} 2 \theta$. Slits are $1.0 \mathrm{~mm}$ (divergence) and $0.1 \mathrm{~mm}$ (receiving) and the sample holder spinning. MacDiff software (version 4.2.5) was utilized to draw a baseline of intensity, smooth counts, correct peak positions offset by misalignment of the detector (using the quartz [100] peak at $20.95^{\circ} 2 \theta$; d-value $=4.24 \AA$ ) , and calcu- 
late integrated peak area (total counts) and peak width at half height $\left(\Delta^{\circ} 2 \theta\right)$.

\section{Calculations of mineral abundance}

To achieve the best possible accuracy, XRD methods require calibration with internal standards, use of single-line reference intensity ratios, and some fairly elaborate sample preparation steps to create optimal random particle orientations (e.g., Środoń et al., 2001; Omotoso et al., 2006). Given the unusually large number of samples throughout the NanTroSEIZE project, our priority has been to obtain reliable semiquantitative accuracy with optimal efficiency. To accomplish that for the clay-size fraction, standard mineral mixtures (smectite + illite + chlorite + quartz) were analyzed as described by Underwood et al. (2003), and a matrix of normalization factors was computed using singular value decomposition (SVD). We record the integrated areas of a broad smectite (001) peak centered at $\sim 5.3^{\circ} 2 \theta$ (d-value $=$ $16.5 \AA$ ), the illite $(001)$ peak at $\sim 8.9^{\circ} 2 \theta$ (d-value $=9.9$ $\AA$ ), the composite chlorite (002) + kaolinite (001) peak at $12.5^{\circ} 2 \theta(\mathrm{d}$-value $=7.06 \AA)$, and the quartz (100) peak at $20.85^{\circ} 2 \theta$ (d-value $\left.=4.26 \AA\right)$. Because of differences in X-ray tubes and diffractometers, it was necessary to solve for three sets of normalization factors (Table T1) and then employ them during computations. Average errors using this method are 3.9\% for smectite, $1.0 \%$ for illite, $1.9 \%$ for chlorite, and $1.6 \%$ for quartz. The chlorite (002) and kaolinite (001) peaks overlap almost completely, so a refined version of the Biscaye (1964) method was used to discriminate kaolinite (002) from chlorite (004), as documented by Guo and Underwood (2011). The average error of accuracy for the chlorite/kaolinite ratio is $2.6 \%$. That ratio was used to compute individual mineral percentages from the SVD weight percent of undifferentiated chlorite (002) + kaolinite (001).

To calculate the abundance of individual clay minerals in the bulk sediment, each relative weight percent value among the clay minerals (where smectite + illite + chlorite + kaolinite $=100 \%$ ) was multiplied by the weight percent of total clay minerals within the bulk powder (where total clay minerals + quartz + feldspar + calcite $=100 \%$ ), as determined by shipboard XRD analyses of collocated specimens (Expedition 333 Scientists, 2012b; also see the "Site C0021" chapter [Strasser et al., 2014b]). To facilitate direct comparisons with other published data sets from the region, tabulations include the weighted peak-area percentages for smectite, illite, and undifferentiated chlorite + kaolinite using Biscaye (1965) weighting factors $(1 \times$ smectite, $4 \times$ illite, and $2 \times$ chlorite + kaolinite). Errors of accuracy using that method can be substantially greater ( $\pm 10 \%$ or more) as compared to the errors using SVD factors (Underwood et al., 2003).

For documentation of clay diagenesis, the saddle/ peak method of Rettke (1981) was used to calculate percent expandability of smectite and illite/smectite (I/S) mixed-layer clay. This method is sensitive to the proportions of discrete illite (I) versus I/S mixed-layer clay; the curve for 1:1 mixtures of I and I/S provides the best match for the range of Nankai specimens. Values of the illite crystallinity (Kübler) index are reported here as peak width at half height $\left(\Delta^{\circ} 2 \theta\right)$ for the (001) reflection; the illite peak typically narrows as levels of thermal maturity increase.

\section{Results}

Tables T2 and T3 show the peak-area values (total counts) for common minerals in the clay-size fraction, segregated by lithologic unit. Tables T2 and T3 also include the values of mineral abundance calculated with SVD normalization factors and weighted peak area (\%) using Biscaye (1965) factors. Values are rounded to the nearest $1 \mathrm{wt} \%$ in acknowledgment of the statistical disadvantages of having to use three sets of SVD normalization factors. In addition, some of these results suffer from unusually low peak intensities caused by relatively high concentrations of biogenic calcite in the clay-size fraction (Table T2).

\section{Site C0018}

Detrital illite is the most abundant clay mineral in the slope basin deposits, followed by detrital smectite. The relative abundance of illite within Subunit Ia ranges from 32 to $46 \mathrm{wt} \%$ (Fig. F3) with a mean value $(\mu)$ of $37.7 \mathrm{wt} \%$ and a standard deviation $(\sigma)$ of 4.2. The amount of smectite in the clay-size fraction ranges from 14 to $38 \mathrm{wt} \%(\mu=26.8 ; \sigma=5.1)$. Percentages of chlorite range from 12 to $36 \mathrm{wt} \%(\mu=20.2 ; \sigma$ $=3.8$ ). Percentages of clay-size kaolinite and quartz are subordinate, averaging $4.1 \mathrm{wt} \%(\sigma=3.4)$ and $11.3 \mathrm{wt} \%(\sigma=4.7)$, respectively. There are no obvious differences in composition between intact hemipelagic deposits and MTDs.

The clay minerals in samples from Subunit Ib are similar to those in overlying deposits (Fig. F3). The range of relative percentages for illite is from 30 to $47 \mathrm{wt} \%(\mu=37.2 ; \sigma=5.3)$, whereas smectite varies from 8 to 39 wt $\%(\mu=23.6 ; \sigma=7.2)$. For 6 specimens, it was impossible to resolve the chlorite/kaolinite ratio because of interference by a strong barite peak (Table T2). The average value for undifferentiated chlorite + kaolinite is $30.7 \mathrm{wt} \%$, and the average for clay-size quartz is $8.5 \mathrm{wt} \%$. 
Figure F4 illustrates how abundances of smectite and illite within the bulk sediment change as a function of depth. Smectite is probably the most influential for modulating frictional and geotechnical properties of the sediment. Within Subunit Ia, bulk sediment smectite ranges from 8 to 18 wt $\%(\mu=13.8 ; \sigma=$ 2.6). Comparable values within Subunit Ib range from 3 to 22 wt $\%(\mu=12.6 ; \sigma=4.6)$.

Illite crystallinity (Kübler) index values for strata within Subunit Ia range from 0.26 to $0.42 \Delta^{\circ} 2 \theta(\mu=$ $0.33 \Delta^{\circ} 2 \theta$ ). The results from Subunit Ib are basically the same $\left(\mu=0.33 \Delta^{\circ} 2 \theta\right)$, with no systematic changes as a function of depth (Fig. F4). As a frame of reference, the boundary between advanced diagenesis and anchizone metamorphism is set at $0.52 \Delta^{\circ} 2 \theta$, and the achizone/epizone boundary (incipient greenschist facies) coincides with $0.32 \Delta^{\circ} 2 \theta$ (Warr and Mählmann, 2015). Deposits from Subunit Ia yield I/S expandability values that range from 48 to $68 \mathrm{wt} \%$ $(\mu=61 \%)$, with no systematic changes as a function of depth (Fig. F4). The average value of I/S expandability for Subunit Ib is $64 \%$.

\section{Site C0021}

The 21 specimens analyzed from Site C0021 (1 replicate) are limited to Subunit Ia and reveal clay mineral assemblages similar to those from Subunit Ia at Site C0018 (Fig. F3). Some of these results also suffer from unusually low peak intensities caused by relatively high concentrations of biogenic calcite (Table T3). The relative abundance of illite in the clay-size fraction ranges from 39 to $52 \mathrm{wt} \%(\mu=43.7 ; \sigma=4.5)$. Smectite abundance ranges from 15 to $38 \mathrm{wt} \%(\mu=$ 23.6; $\sigma=5.2$ ). Chlorite remains consistently subordinate, ranging from 9 to $27 \mathrm{wt} \%(\mu=19.5 ; \sigma=4.5)$, whereas clay-size kaolinite $(\mu=4.8 ; \sigma=3.8)$ and quartz $(\mu=8.4 ; \sigma=5.3)$ remain consistently low. Calculated values of smectite in bulk sediment (Fig. F4) range from 7 to $22 \mathrm{wt} \%(\mu=11.7, \sigma=3.2)$. Illite crystallinity (Kübler) index values range from 0.21 to $0.42 \Delta^{\circ} 2 \theta$ (Fig. F4), with an average value of $0.35 \Delta^{\circ} 2 \theta$ (i.e., mostly anchizone source rocks). The expandability of I/S clays ranges from $49 \%$ to $66 \%$, with an average value of $58 \%$.

\section{Acknowledgments}

This research used samples provided by the Integrated Ocean Drilling Program (IODP). We thank the Mantle Quest Japan drilling crew, Marine Works Japan laboratory technicians, and scientists aboard D/V Chikyu for their dedicated assistance during IODP Expeditions 333 and 338. Funding was granted by the Consortium for Ocean Leadership, U.S. Science Sup- port Program (task orders T333B58 and T338B58). N. Walla, J. Guo, K. Ekinci, and C. Song assisted with sample preparation. The manuscript was reviewed by Tania Villaseñor.

\section{References}

Ashi, J., Lallemant, S., Masago, H., and the Expedition 315 Scientists, 2009. Expedition 315 summary. In Kinoshita, M., Tobin, H., Ashi, J., Kimura, G., Lallemant, S., Screaton, E.J., Curewitz, D., Masago, H., Moe, K.T., and the Expedition 314/315/316 Scientists, Proceedings of the Integrated Ocean Drilling Program, 314/315/316: Washington, DC (Integrated Ocean Drilling Program Management International, Inc.). http://dx.doi.org/ 10.2204/iodp.proc.314315316.121.2009

Biscaye, P.E., 1964. Distinction between kaolinite and chlorite in recent sediments by X-ray diffraction. American Mineralogist, 49:1281-1289. http://www.minsocam.org/ammin/AM49/AM49_1281.pdf

Biscaye, P.E., 1965. Mineralogy and sedimentation of recent deep-sea clay in the Atlantic Ocean and adjacent seas and oceans. Geological Society of America Bulletin, 76(7):803-831. http://dx.doi.org/10.1130/00167606(1965)76[803:MASORD]2.0.CO;2

Expedition 333 Scientists, 2012a. Expedition 333 summary. In Henry, P., Kanamatsu, T., Moe, K., and the Expedition 333 Scientists, Proceedings of the Integrated Ocean Drilling Program, 333: Tokyo (Integrated Ocean Drilling Program Management International, Inc.). http://dx.doi.org/10.2204/iodp.proc.333.101.2012

Expedition 333 Scientists, 2012b. Site C0018. In Henry, P., Kanamatsu, T., Moe, K., and the Expedition 333 Scientists, Proceedings of the Integrated Ocean Drilling Program, 333: Tokyo (Integrated Ocean Drilling Program Management International, Inc.). http://dx.doi.org/10.2204/ iodp.proc.333.103.2012

Guo, J., and Underwood, M.B., 2011. Data report: refined method for calculating percentages of kaolinite and chlorite from X-ray diffraction data, with application to the Nankai margin of southwest Japan. In Kinoshita, M., Tobin, H., Ashi, J., Kimura, G., Lallemant, S., Screaton, E.J., Curewitz, D., Masago, H., Moe, K.T., and the Expedition 314/315/316 Scientists, Proceedings of the Integrated Ocean Drilling Program, 314/315/316: Washington, DC (Integrated Ocean Drilling Program Management International, Inc.). http://dx.doi.org/ 10.2204/iodp.proc.314315316.201.2011

Guo, J., and Underwood, M.B., 2012. Data report: clay mineral assemblages from the Nankai Trough accretionary prism and the Kumano Basin, IODP Expeditions 315 and 316, NanTroSEIZE Stage 1. In Kinoshita, M., Tobin, H., Ashi, J., Kimura, G., Lallemant, S., Screaton, E.J., Curewitz, D., Masago, H., Moe, K.T., and the Expedition 314/315/316 Scientists, Proceedings of the Integrated Ocean Drilling Program, 314/315/316: Washington, DC (Integrated Ocean Drilling Program Management International, Inc.). http://dx.doi.org/10.2204/

iodp.proc.314315316.202.2012 
Moore, D.M., and Reynolds, R.C., Jr., 1989. Sample preparation techniques for clay minerals. In Moore, D.M., and Reynolds, R.C., Jr. (Eds.), X-Ray Diffraction and the Identification and Analysis of Clay Minerals: New York (Oxford Univ. Press USA), 179-201.

Omotoso, O., McCarty, D.K., Hillier, S., and Kleeberg, R., 2006. Some successful approaches to quantitative mineral analysis as revealed by the 3rd Reynolds Cup contest. Clays and Clay Minerals, 54(6):748-760. http:// dx.doi.org/10.1346/CCMN.2006.0540609

Rettke, R.C., 1981. Probable burial diagenetic and provenance effects on Dakota Group clay mineralogy, Denver Basin. Journal of Sedimentary Petrology, 51(2):541-551. http://dx.doi.org/10.1306/212F7CCF-2B24-11D78648000102C1865D

Screaton, E.J., Kimura, G., Curewitz, D., and the Expedition 316 Scientists, 2009. Expedition 316 summary. In Kinoshita, M., Tobin, H., Ashi, J., Kimura, G., Lallemant, S., Screaton, E.J., Curewitz, D., Masago, H., Moe, K.T., and the Expedition 314/315/316 Scientists, Proceedings of the Integrated Ocean Drilling Program, 314/315/ 316: Washington, DC (Integrated Ocean Drilling Program Management International, Inc.). http:// dx.doi.org/10.2204/iodp.proc.314315316.131.2009

Środoń, J., Drits, V.A., McCarty, D.K., Hsieh, J.C.C., and Eberl, D.D., 2001. Quantitative X-ray diffraction analysis of clay-bearing rocks from random preparations. Clays and Clay Minerals, 49(6):514-528. http:// ccm.geoscienceworld.org/cgi/content/abstract/49/ 6/514

Strasser, M., Dugan, B., Kanagawa, K., Moore, G.F., Toczko, S., Maeda, L., Kido, Y., Moe, K.T., Sanada, Y., Esteban, L., Fabbri, O., Geersen, J., Hammerschmidt, S., Hayashi, H., Heirman, K., Hüpers, A., Jurado Rodriguez, M.J., Kameo, K., Kanamatsu, T., Kitajima, H., Masuda, H., Milliken, K., Mishra, R., Motoyama, I., Olcott, K., Oohashi, K., Pickering, K.T., Ramirez, S.G., Rashid, H., Sawyer, D., Schleicher, A., Shan, Y., Skarbek, R., Song, I., Takeshita, T., Toki, T., Tudge, J., Webb, S., Wilson, D.J., Wu, H.-Y., and Yamaguchi, A., 2014a. Expedition 338 summary. In Strasser, M., Dugan, B., Kanagawa, K., Moore, G.F., Toczko, S., Maeda, L., and the Expedition 338 Scientists, Proceedings of the Integrated Ocean Drilling Program, 338: Yokohama (Integrated Ocean Drilling Program). http:// dx.doi.org/10.2204/iodp.proc.338.101.2014

Strasser, M., Dugan, B., Kanagawa, K., Moore, G.F., Toczko, S., Maeda, L., Kido, Y., Moe, K.T., Sanada, Y., Esteban, L., Fabbri, O., Geersen, J., Hammerschmidt, S., Hayashi, H., Heirman, K., Hüpers, A., Jurado Rodriguez, M.J., Kameo, K., Kanamatsu, T., Kitajima, H., Masuda, H., Milliken, K., Mishra, R., Motoyama, I., Olcott, K., Oohashi, K., Pickering, K.T., Ramirez, S.G., Rashid, H., Sawyer, D., Schleicher, A., Shan, Y., Skarbek, R., Song, I., Takeshita, T., Toki, T., Tudge, J., Webb, S., Wilson, D.J., Wu, H.-Y., and Yamaguchi, A., 2014b. Site C0002. In Strasser, M., Dugan, B., Kanagawa, K., Moore, G.F., Toczko, S., Maeda, L., and the Expedition 338 Scientists, Proceedings of the Integrated Ocean Drilling Program, 338: Yokohama (Integrated Ocean Drilling Program). http:// dx.doi.org/10.2204/iodp.proc.338.103.2014
Tobin, H., Hirose, T., Saffer, D., Toczko, S., Maeda, L., Kubo, Y., Boston, B., Broderick, A., Brown, K., Crespo-Blanc, A., Even, E., Fuchida, S., Fukuchi, R., Hammerschmidt, S., Henry, P., Josh, M., Jurado, M.J., Kitajima, H., Kitamura, M., Maia, A., Otsubo, M., Sample, J., Schleicher, A., Sone, H., Song, C., Valdez, R., Yamamoto, Y., Yang, K., Sanada, Y., Kido, Y., and Hamada, Y., 2015. Expedition 348 summary. In Tobin, H., Hirose, T., Saffer, D., Toczko, S., Maeda, L., Kubo, Y., and the Expedition 348 Scientists, Proceedings of the Integrated Ocean Drilling Program, 348: College Station, TX (Integrated Ocean Drilling Program). http://dx.doi.org/10.2204/ iodp.proc.348.101.2015

Tobin, H., Kinoshita, M., Ashi, J., Lallemant, S., Kimura, G., Screaton, E.J., Moe, K.T., Masago, H., Curewitz, D., and the Expedition 314/315/316 Scientists, 2009. NanTroSEIZE Stage 1 expeditions: introduction and synthesis of key results. In Kinoshita, M., Tobin, H., Ashi, J., Kimura, G., Lallemant, S., Screaton, E.J., Curewitz, D., Masago, H., Moe, K.T., and the Expedition 314/315/316 Scientists, Proceedings of the Integrated Ocean Drilling Program, 314/315/316: Washington, DC (Integrated Ocean Drilling Program Management International, Inc.). http://dx.doi.org/10.2204/ iodp.proc.314315316.101.2009

Underwood, M.B., Basu, N., Steurer, J., and Udas, S., 2003. Data report: normalization factors for semiquantitative X-ray diffraction analysis, with application to DSDP Site 297, Shikoku Basin. In Mikada, H., Moore, G.F., Taira, A., Becker, K., Moore, J.C., and Klaus, A. (Eds.), Proceedings of the Ocean Drilling Program, Scientific Results, 190/ 196: College Station, TX (Ocean Drilling Program), 128. http://dx.doi.org/10.2973/ odp.proc.sr.190196.203.2003

Underwood, M.B., and Guo, J., 2013. Data report: clay mineral assemblages in the Shikoku Basin, NanTroSEIZE subduction inputs, IODP Sites C0011 and C0012. In Saito, S., Underwood, M.B., Kubo, Y., and the Expedition 322 Scientists, Proceedings of the Integrated Ocean Drilling Program, 322: Tokyo (Integrated Ocean Drilling Program Management International, Inc.). http:// dx.doi.org/10.2204/iodp.proc.322.202.2013

Underwood, M.B., Saito, S., Kubo, Y., and the Expedition 322 Scientists, 2010. Expedition 322 summary. In Saito, S., Underwood, M.B., Kubo, Y., and the Expedition 322 Scientists, Proceedings of the Integrated Ocean Drilling Program, 322: Tokyo (Integrated Ocean Drilling Program Management International, Inc.). http://dx.doi.org/ 10.2204/iodp.proc.322.101.2010

Warr, L.N., and Mählmann, R.F., 2015. Recommendations for Kübler Index standardization. Clay Minerals, 50(3):283-286. http://dx.doi.org/10.1180/clay$\min .2015 .050 .3 .02$

Initial receipt: 28 June 2016

Acceptance: 16 November 2016

Publication: 9 February 2017

MS 338-207 
Figure F1. Nankai Trough study area (NanTroSEIZE transect) with locations of Sites C0018 and C0021. White circles $=$ locations of other NanTroSEIZE drill sites along the Kumano transect.

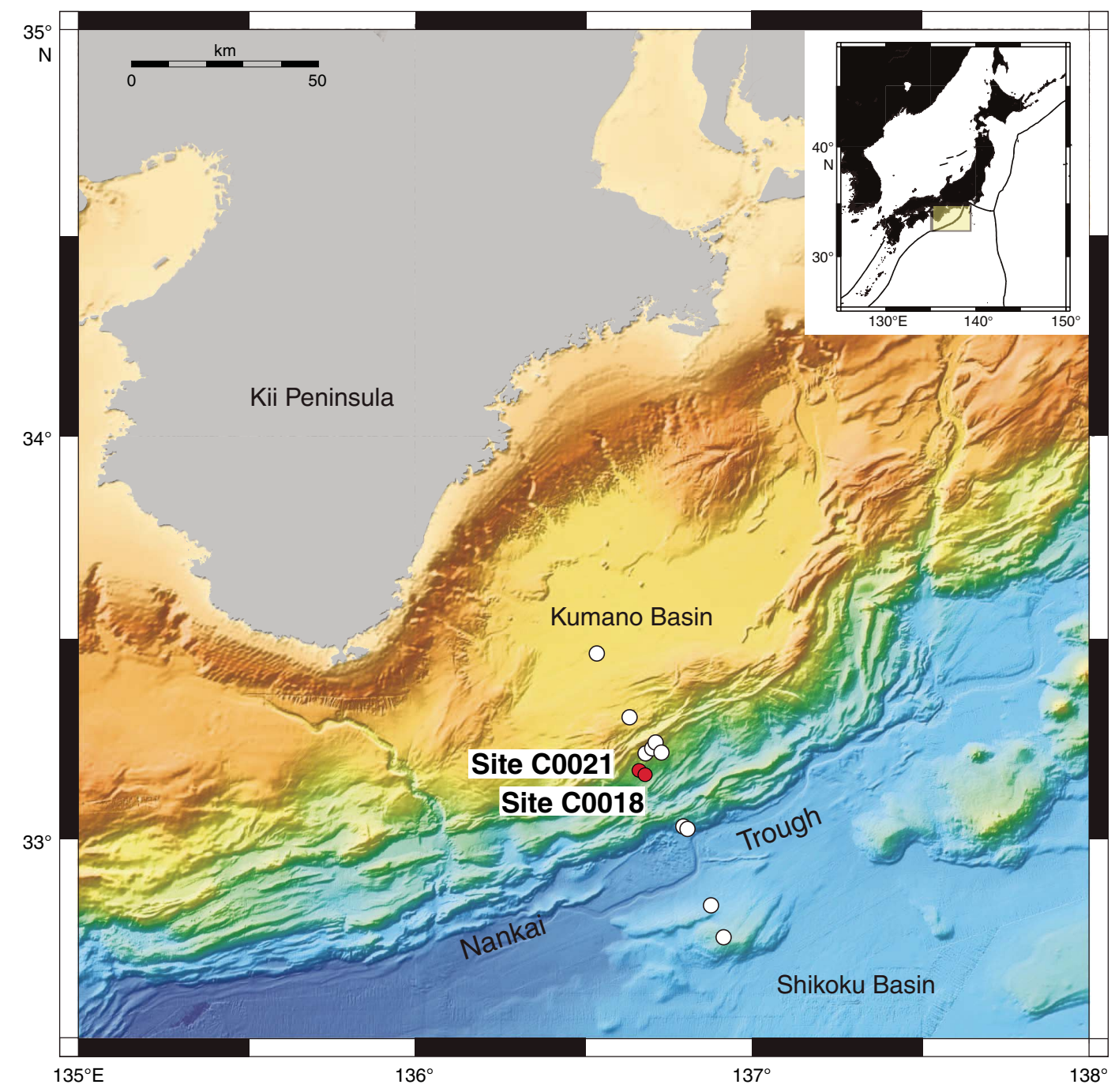


Figure F2. Bathymetry and seismic section crossing the slope basin of Nankai Trough with locations of Sites C0018 and C0021 (see the "Expedition 338 summary" chapter [Strasser et al., 2014a]).

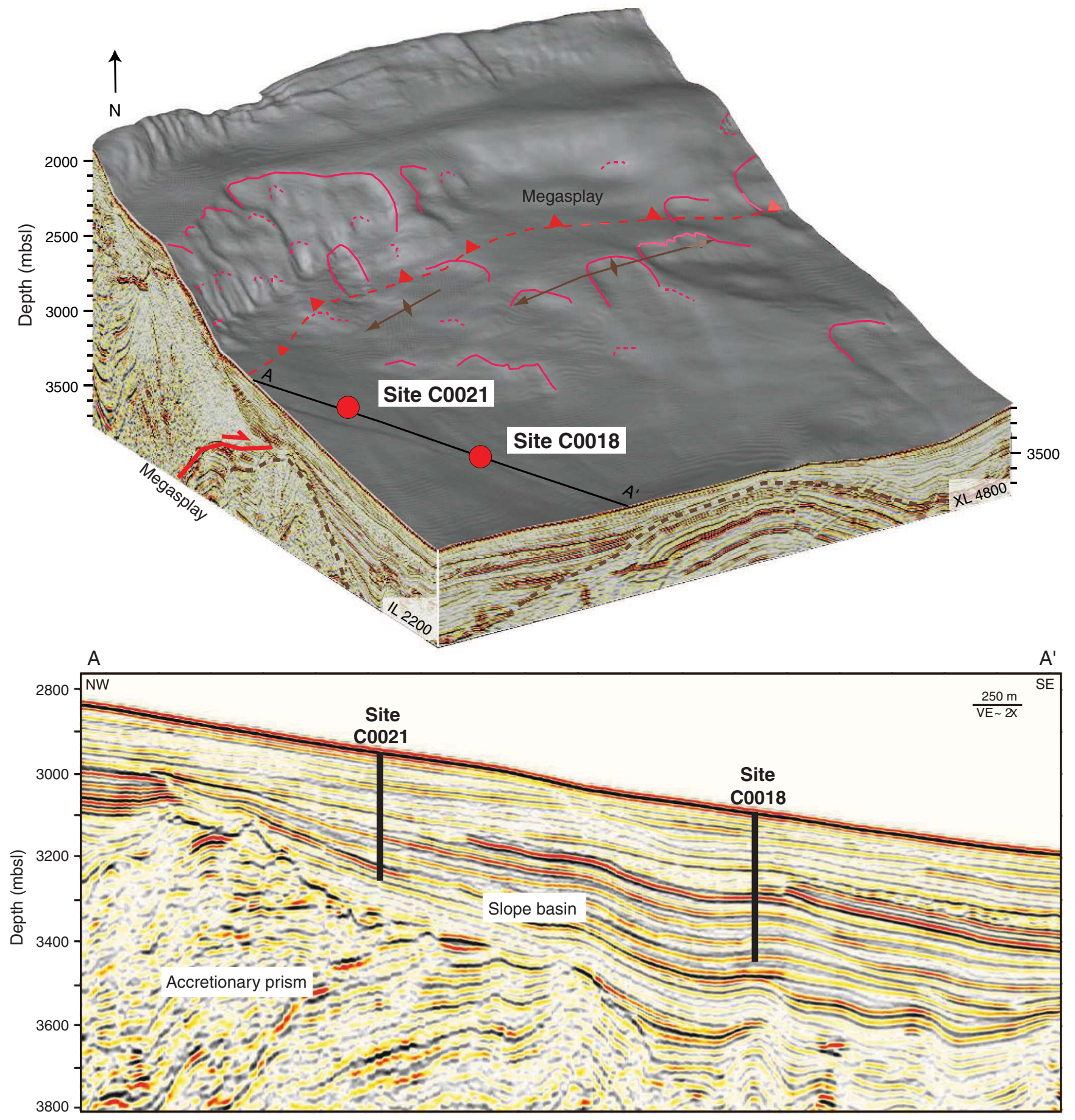


Figure F3. Depth distribution of the calculated relative abundances of smectite, illite, chlorite + kaolinite, and quartz within the clay-size fraction of core samples from Sites C0018 (solid symbols) and C0021 (open symbols) (see the "Expedition 338 summary" chapter [Strasser et al., 2014a]).

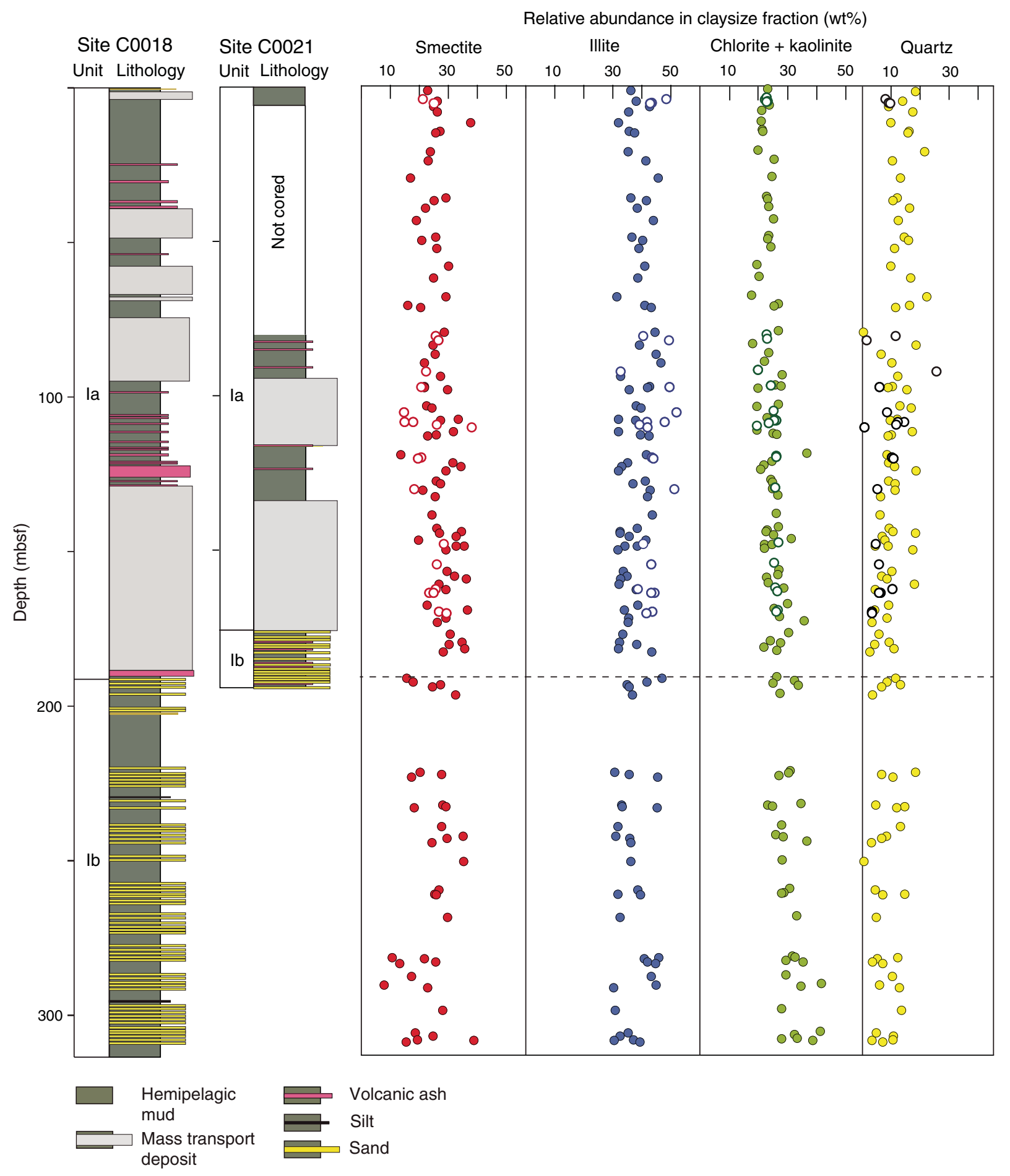


Figure F4. Depth distribution of total clay minerals (Expedition 333 Scientists, 2012b; also see the "Site C0021" chapter [Strasser et al., 2014b]), smectite in bulk sediment, illite in bulk sediment, illite/smectite (I/S) expandability, and illite crystallinity index. Results are from the clay-size fraction of core samples from Sites C0018 (solid symbols) and C0021 (open symbols) (see the "Expedition 338 summary" chapter [Strasser et al., 2014a]). Boundaries for anchizone and epizone metamorphism are from Warr and Mählmann (2015).

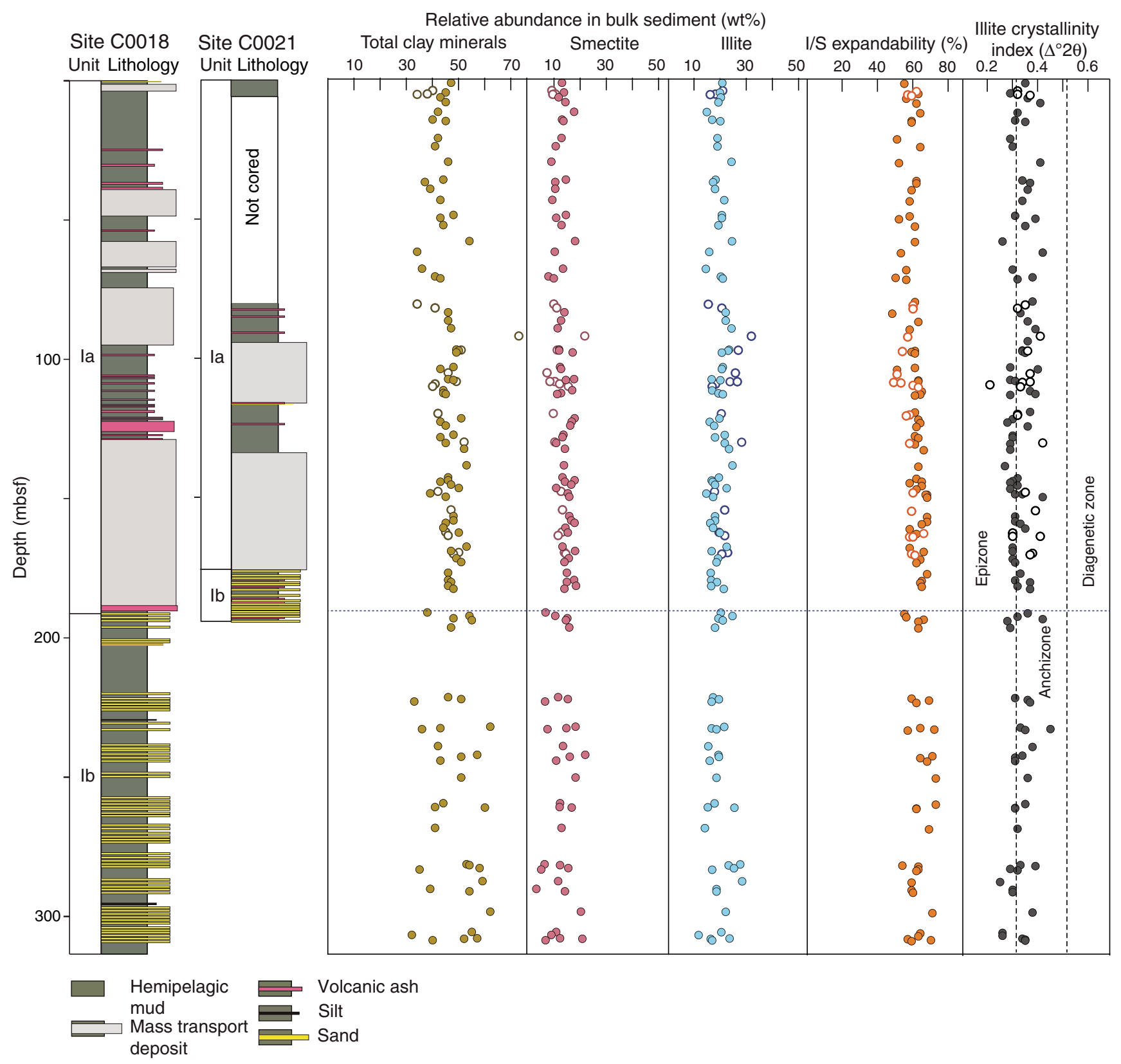


Table T1. Matrix of normalization factors used to calculate relative mineral abundances in clay-size aggregates and derived from singular value decomposition.

\begin{tabular}{lcccc}
\hline \multirow{2}{*}{$\begin{array}{l}\text { Influencing } \\
\text { mineral }\end{array}$} & Smectite & Illite & Chlorite & Quartz \\
\cline { 2 - 5 } & & & & \\
Set 1: University & of Missouri & & & \\
Smectite & 0.0003739856 & -0.0000289946 & -0.0000343775 & -0.0000744212 \\
Illite & 0.0000427201 & 0.0012499784 & -0.0000283639 & 0.0000338385 \\
Chorite & -0.0000676622 & -0.0000002008 & 0.0007697485 & 0.0000524088 \\
Quartz & 0.0024368789 & 0.0009231154 & 0.0008195109 & 0.0037061975 \\
Set 2: University & of Missouri & & & \\
Smectite & 0.0003906885 & -0.0000299673 & -0.0000144669 & -0.0000616869 \\
Illite & -0.0001143631 & 0.0011302975 & 0.0000131880 & 0.0000447713 \\
Chorite & -0.0001578547 & -0.0000114816 & 0.0006907853 & 0.0000047565 \\
Quartz & 0.0037122953 & 0.0014025429 & 0.0005607141 & 0.0043742270 \\
Set 3: New Mexico Bureau of Geology & and Mineral Resources & & \\
Smectite & 0.0007447529 & -0.0000319536 & -0.0000750672 & -0.0001566192 \\
Illite & 0.0000631147 & 0.0037866938 & 0.0000842230 & 0.0001176929 \\
Chorite & -0.0003563606 & -0.0000673781 & 0.0025121504 & 0.0000522907 \\
Quartz & 0.0093573136 & 0.0036491468 & 0.0032755411 & 0.0148256450 \\
\hline
\end{tabular}


Table T2. X-ray diffraction analyses results for core samples ( $<2 \mu \mathrm{m}$ size fraction), Site C0018. (Continued on next two pages.)

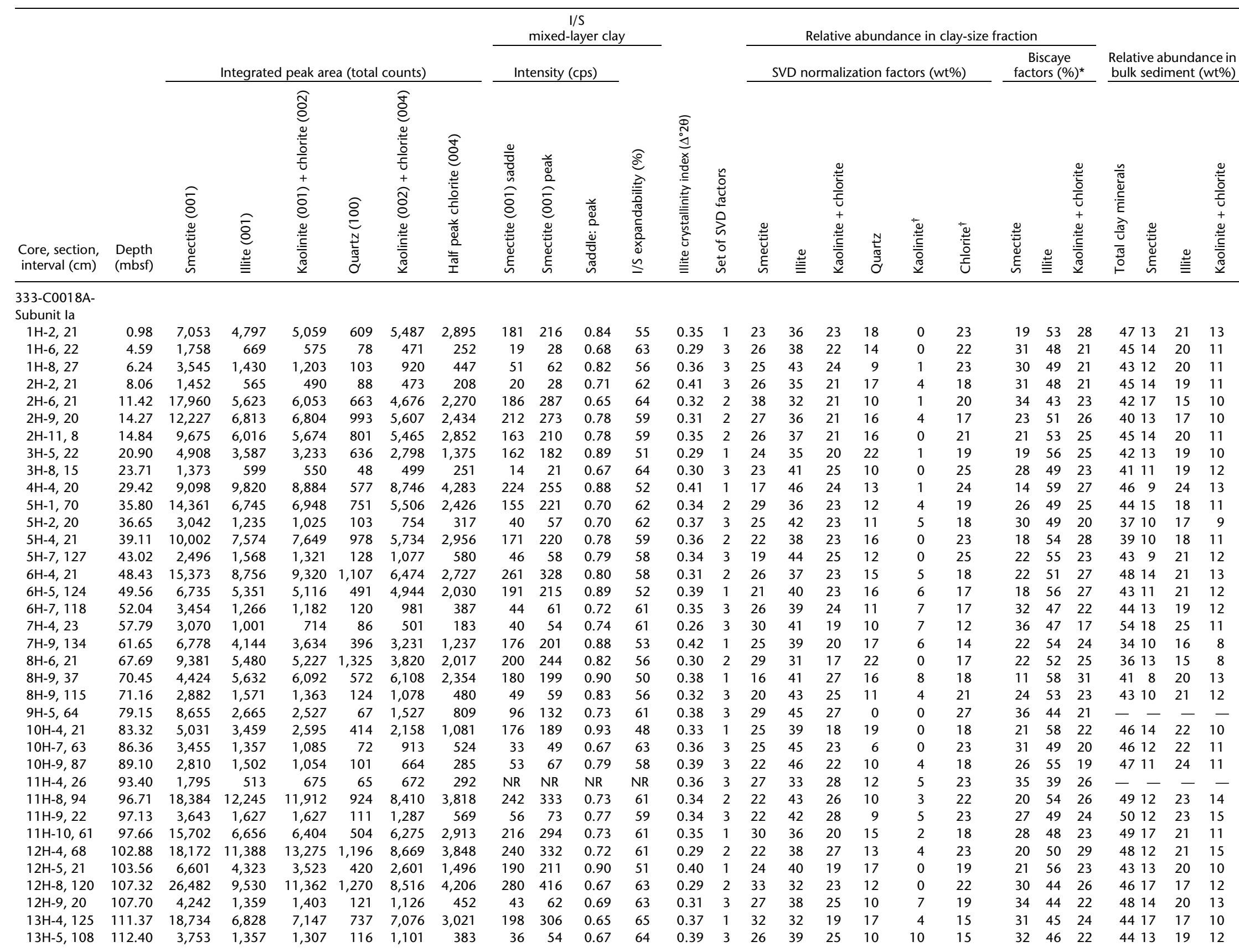


Table T2 (continued). (Continued on next page.)

\begin{tabular}{|c|c|c|c|c|c|c|c|c|c|c|c|c|c|c|c|c|c|c|c|c|c|c|c|c|c|}
\hline \multirow[b]{3}{*}{$\begin{array}{l}\text { Core, section, } \\
\text { interval }(\mathrm{cm})\end{array}$} & \multirow[b]{3}{*}{$\begin{array}{l}\text { Depth } \\
\text { (mbsf) }\end{array}$} & & & & & & & \multicolumn{4}{|c|}{$\begin{array}{c}\mathrm{I} / \mathrm{S} \\
\text { mixed-layer clay }\end{array}$} & \multicolumn{11}{|c|}{ Relative abundance in clay-size fraction } & \multirow{2}{*}{\multicolumn{3}{|c|}{$\begin{array}{l}\text { Relative abundance in } \\
\text { bulk sediment (wt\%) }\end{array}$}} \\
\hline & & \multicolumn{6}{|c|}{ Integrated peak area (total counts) } & \multicolumn{3}{|c|}{ Intensity (cps) } & \multirow[b]{2}{*}{ 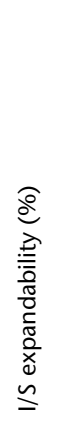 } & \multirow[b]{2}{*}{ 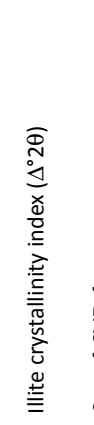 } & \multirow[b]{2}{*}{ 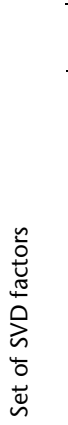 } & \multicolumn{6}{|c|}{ SVD normalization factors (wt\%) } & \multicolumn{3}{|c|}{$\begin{array}{c}\text { Biscaye } \\
\text { factors }(\%)^{*}\end{array}$} & & & \\
\hline & & 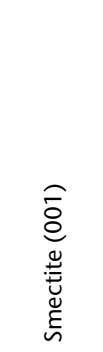 & $\begin{array}{l}\widehat{\bar{\delta}} \\
\bar{o} \\
\stackrel{\underline{\underline{E}}}{=}\end{array}$ & 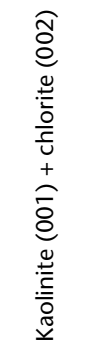 & 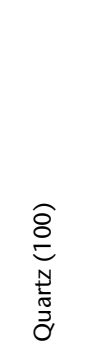 & 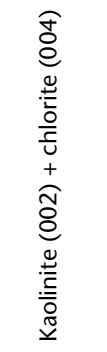 & 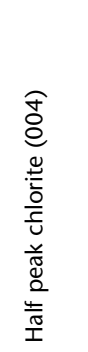 & 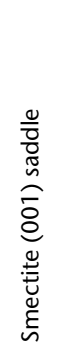 & 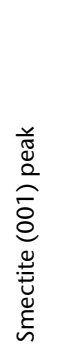 & 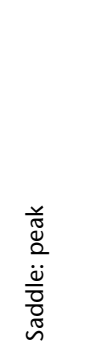 & & & & 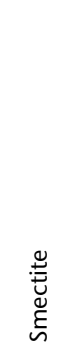 & $\stackrel{\stackrel{\mathscr{E}}{=}}{=}$ & 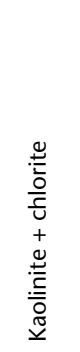 & $\begin{array}{l}\frac{1}{0} \\
\frac{0}{0} \\
\frac{0}{\pi}\end{array}$ & 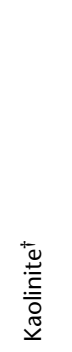 & 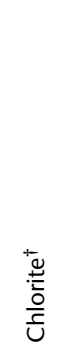 & 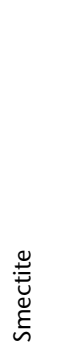 & $\stackrel{\stackrel{s}{=}}{=}$ & 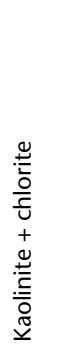 & 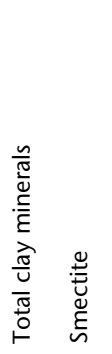 & $\stackrel{\stackrel{\Xi}{=}}{=}$ & 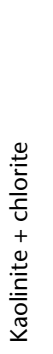 \\
\hline $13 \mathrm{H}-6,22$ & 112.67 & 4,960 & 2,143 & 2,000 & 145 & 1,676 & 681 & 62 & 85 & 0.73 & 61 & 0.29 & 3 & 23 & 42 & 26 & 9 & 7 & 19 & 28 & 49 & 23 & 4511 & 21 & 13 \\
\hline $14 \mathrm{H}-2,19$ & 118.78 & 2,839 & 1,878 & 2,474 & 107 & 1,851 & 647 & 51 & 69 & 0.74 & 61 & 0.37 & 3 & 14 & 42 & 36 & 9 & 15 & 22 & 19 & 49 & 32 & $-\quad-$ & - & - \\
\hline $14 \mathrm{H}-4,20$ & 121.37 & 31,362 & 12,258 & 14,038 & 1,152 & 9,831 & 3,545 & 302 & 442 & 0.68 & 63 & 0.30 & 2 & 32 & 35 & 25 & 9 & 9 & 15 & 29 & 45 & 26 & 5118 & 20 & 14 \\
\hline $14 \mathrm{H}-5,21$ & 122.64 & 25,441 & 9,180 & 9,899 & 1,110 & 7,053 & 3,204 & 266 & 398 & 0.67 & 64 & 0.28 & 2 & 34 & 33 & 22 & 11 & 3 & 19 & 31 & 45 & 24 & 4317 & 16 & 10 \\
\hline $14 \mathrm{H}-6,128$ & 123.93 & 12,102 & 5,029 & 5,486 & 664 & 5,568 & 2,493 & 174 & 244 & 0.71 & 62 & 0.36 & 1 & 29 & 32 & 21 & 19 & 3 & 18 & 28 & 47 & 25 & 4516 & 18 & 11 \\
\hline $15 \mathrm{H}-2,65$ & 127.31 & 4,802 & 1,794 & 1,603 & 136 & 1,152 & 540 & 60 & 83 & 0.72 & 61 & 0.30 & 3 & 26 & 41 & 24 & 9 & 2 & 22 & 32 & 47 & 21 & 4814 & 22 & 13 \\
\hline $15 \mathrm{H}-3,33$ & 128.07 & 5,902 & 1,925 & 1,962 & 199 & 1,416 & 633 & 64 & 92 & 0.70 & 63 & 0.30 & 3 & 27 & 37 & 25 & 11 & 4 & 21 & 34 & 44 & 22 & 4313 & 18 & 12 \\
\hline $15 \mathrm{H}-5,22$ & 130.27 & 3,969 & 2,029 & 1,752 & 163 & 1,386 & 594 & 57 & 78 & 0.73 & 61 & 0.29 & 3 & 21 & 43 & 25 & 11 & 5 & 20 & 25 & 52 & 22 & 4511 & 22 & 13 \\
\hline $15 \mathrm{H}-7,80$ & 132.26 & 40,689 & 21,001 & 21,283 & 1,160 & 15,386 & 6,560 & 385 & 635 & 0.61 & 66 & 0.29 & 2 & 25 & 42 & 26 & 6 & 5 & 21 & 24 & 50 & 25 & 5214 & 23 & 15 \\
\hline $16 \mathrm{H}-2,60$ & 138.22 & 7,093 & 2,783 & 2,550 & 147 & 1,945 & 795 & 77 & 113 & 0.68 & 63 & 0.27 & 3 & 24 & 44 & 26 & 6 & 7 & 20 & 30 & 48 & 22 & 5314 & 25 & 15 \\
\hline $16 \mathrm{H}-11,12$ & 142.57 & 4,311 & 1,463 & 1,556 & 121 & 1,050 & 428 & 55 & 77 & 0.71 & 62 & 0.32 & 3 & 26 & 38 & 27 & 9 & 7 & 20 & 32 & 44 & 23 & 4613 & 19 & 13 \\
\hline $16 \mathrm{H}-11,122$ & 143.66 & 25,117 & 8,673 & 10,032 & 1,021 & 7,357 & 3,052 & 263 & 408 & 0.64 & 65 & 0.30 & 2 & 35 & 32 & 23 & 11 & 5 & 17 & 31 & 43 & 25 & 4618 & 17 & 12 \\
\hline $16 \mathrm{H}-12,25$ & 144.10 & 9,047 & 4,244 & 4,956 & 562 & 4,990 & 2,069 & 174 & 217 & 0.80 & 58 & 0.29 & 1 & 27 & 32 & 22 & 18 & 5 & 17 & 25 & 47 & 28 & 4314 & 17 & 12 \\
\hline $17 \mathrm{H}-1,50$ & 145.11 & 37,014 & 13,709 & 15,634 & 1,065 & 11,414 & 4,579 & 359 & 576 & 0.62 & 65 & 0.32 & 2 & 33 & 36 & 25 & 7 & 7 & 18 & 30 & 45 & 25 & 4716 & 18 & 13 \\
\hline $17 \mathrm{H}-2,39$ & 146.32 & 4,943 & 2,261 & 2,588 & 135 & 2,161 & 806 & 65 & 91 & 0.71 & 62 & 0.29 & 3 & 20 & 41 & 31 & 8 & 11 & 21 & 26 & 47 & 27 & 5011 & 22 & 17 \\
\hline $17 \mathrm{H}-3,110$ & 148.28 & 31,379 & 10,898 & 11,429 & 1,086 & 8,008 & 3,327 & 242 & 424 & 0.57 & 68 & 0.34 & 2 & 35 & 34 & 22 & 9 & 5 & 17 & 32 & 45 & 23 & 3915 & 15 & 9 \\
\hline $17 \mathrm{H}-3,116$ & 148.34 & 6,463 & 1,626 & 1,636 & 99 & 1,412 & 582 & 53 & 91 & 0.58 & 67 & 0.31 & 3 & 33 & 38 & 25 & 5 & 6 & 19 & 40 & 40 & 20 & $-\quad-$ & - & - \\
\hline $17 \mathrm{H}-5,26$ & 149.43 & 15,757 & 6,285 & 7,404 & 715 & 7,403 & 3,233 & 154 & 275 & 0.56 & 68 & 0.42 & 1 & 29 & 32 & 22 & 17 & 4 & 18 & 28 & 45 & 27 & 4516 & 17 & 12 \\
\hline $18 \mathrm{H}-3,11$ & 156.35 & 4,098 & 1,064 & 1,324 & 116 & 1,034 & 497 & 32 & 57 & 0.56 & 68 & 0.31 & 3 & 30 & 34 & 27 & 10 & 2 & 26 & 37 & 39 & 24 & 4816 & 18 & 14 \\
\hline $18 \mathrm{H}-4,27$ & 157.95 & 38,202 & 13,974 & 17,130 & 1,083 & 12,327 & 5,028 & 271 & 481 & 0.56 & 68 & 0.31 & 2 & 32 & 35 & 26 & 7 & 7 & 20 & 30 & 44 & 27 & 4816 & 18 & 14 \\
\hline $18 \mathrm{H}-5,98$ & 158.88 & 39,096 & 12,653 & 14,384 & 1,302 & 9,608 & 3,829 & 346 & 552 & 0.63 & 65 & 0.33 & 2 & 36 & 33 & 23 & 9 & 6 & 16 & 33 & 43 & 24 & 4518 & 16 & 11 \\
\hline $19 \mathrm{H}-1,121$ & 160.67 & 8,947 & 4,111 & 5,032 & 521 & 4,785 & 2,445 & 189 & 239 & 0.79 & 58 & 0.35 & 1 & 27 & 32 & 23 & 18 & 0 & 23 & 25 & 46 & 28 & 4414 & 17 & 12 \\
\hline $19 \mathrm{H}-3,46$ & 162.39 & 5,587 & 1,522 & 1,780 & 87 & 1,157 & 581 & 68 & 95 & 0.72 & 62 & 0.30 & 3 & 29 & 38 & 29 & 5 & 0 & 29 & 37 & 40 & 23 & 5015 & 20 & 15 \\
\hline $20 \mathrm{H}-3,123$ & 167.36 & 4,250 & 1,643 & 1,934 & 127 & 1,608 & 621 & 64 & 81 & 0.79 & 58 & 0.30 & 3 & 23 & 39 & 30 & 9 & 9 & 21 & 29 & 45 & 26 & 5313 & 22 & 17 \\
\hline $20 \mathrm{H}-5,21$ & 168.89 & 42,520 & 13,241 & 15,793 & 875 & 10,920 & 4,248 & 352 & 569 & 0.62 & 66 & 0.30 & 2 & 37 & 34 & 25 & 4 & 8 & 18 & 33 & 42 & 25 & 4718 & 17 & 12 \\
\hline $20 \mathrm{H}-7,129$ & 171.54 & 32,915 & 13,643 & 17,044 & 1,182 & 13,022 & 6,181 & 364 & 544 & 0.67 & 64 & 0.30 & 2 & 29 & 35 & 27 & 9 & 2 & 25 & 27 & 45 & 28 & 4916 & 19 & 15 \\
\hline $20 \mathrm{H}-8,119$ & 172.83 & 7,290 & 1,931 & 3,002 & 97 & 2,595 & 1,330 & 78 & 109 & 0.72 & 62 & 0.31 & 3 & 26 & 35 & 36 & 3 & 0 & 36 & 35 & 37 & 29 & 5114 & 19 & 19 \\
\hline $21 \mathrm{H}-3,20$ & 176.79 & 50,372 & 17,752 & 25,982 & 1,298 & 17,930 & 8,336 & 388 & 692 & 0.56 & 68 & 0.33 & 2 & 31 & 33 & 30 & 6 & 3 & 27 & 29 & 41 & 30 & 4615 & 16 & 15 \\
\hline $22 \mathrm{H}-2,35$ & 179.26 & 33,735 & 11,253 & 13,621 & 1,211 & 9,314 & 4,123 & 324 & 520 & 0.62 & 65 & 0.31 & 2 & 35 & 32 & 24 & 9 & 4 & 20 & 32 & 42 & 26 & 4618 & 16 & 12 \\
\hline $22 \mathrm{H}-2,110$ & 180.01 & 8,588 & 2,269 & 2,554 & 128 & 1,859 & 640 & 90 & 136 & 0.66 & 64 & 0.37 & 3 & 30 & 38 & 27 & 4 & 11 & 16 & 38 & 40 & 22 & 4715 & 19 & 13 \\
\hline $22 \mathrm{H}-5,30$ & 181.35 & 24,256 & 8,093 & 9,164 & 1,021 & 7,015 & 3,405 & 252 & 396 & 0.64 & 65 & 0.32 & 2 & 36 & 32 & 22 & 11 & 1 & 21 & 32 & 43 & 24 & 4618 & 16 & 11 \\
\hline \multirow[t]{3}{*}{$22 \mathrm{H}-7,55$} & 182.39 & 3,965 & 1,246 & 1,179 & 46 & 990 & 352 & NR & NR & NR & NR & 0.37 & 3 & 28.1 & 43.3 & 26.1 & 2.5 & 10.1 & 16.0 & 35 & 44 & 21 & 4814 & 21 & 13 \\
\hline & & & & & & & & & & Average: & 61 & 0.332 & & 26.8 & 37.7 & 24.2 & 11.3 & 4.1 & 20.2 & & & & 13.8 & 19.3 & 12.3 \\
\hline & & & & & & & & & & & Stanc & ard devia & iation: & 5.1 & 4.2 & 3.6 & 4.7 & 3.4 & 3.8 & & & & 2.6 & 2.6 & 2.0 \\
\hline Subunit lb & & & & & & & & & & & & & & & & & & & & & & & & & \\
\hline $24 \mathrm{~T}-1,36$ & 191.01 & 3,270 & 2,657 & 2,186 & 179 & Barite & & 61 & 73 & 0.84 & 55 & 0.36 & 3 & 16 & 47 & 26 & 12 & & ite & 18 & 58 & 24 & 387 & 20 & 11 \\
\hline $24 \mathrm{~T}-2,20$ & 192.26 & 4,009 & 2,096 & 2,445 & 129 & 1,597 & 665 & 68 & 83 & 0.82 & 56 & 0.32 & 3 & 18 & 42 & 32 & 9 & 7 & 25 & 23 & 49 & 28 & 5410 & 25 & 19 \\
\hline $24 \mathrm{~T}-2,102$ & 193.08 & 23,553 & 10,094 & 12,380 & 533 & 11,743 & 4,483 & 242 & 395 & 0.61 & 66 & 0.42 & 1 & 27 & 35 & 25 & 13 & 8 & 17 & 27 & 46 & 28 & 4815 & 19 & 14 \\
\hline
\end{tabular}




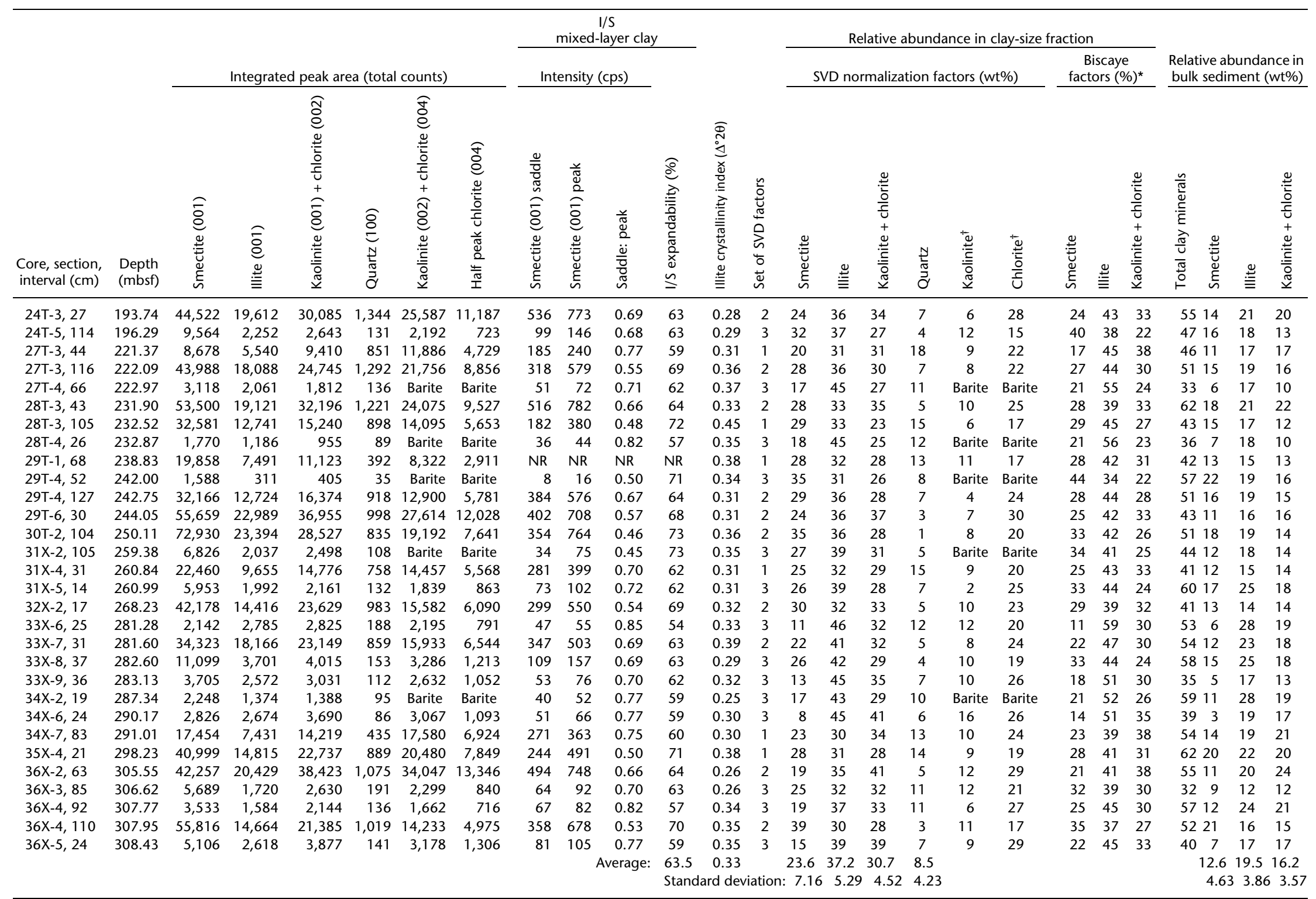

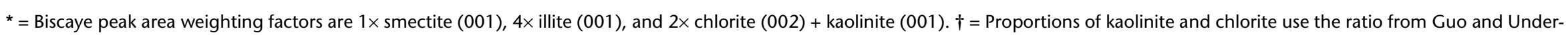

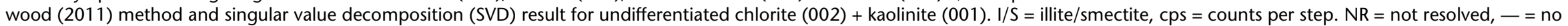
data. 
Table T3. Results of X-ray diffraction analyses for core samples ( $<2 \mu \mathrm{m}$ size fraction), Site C0021.

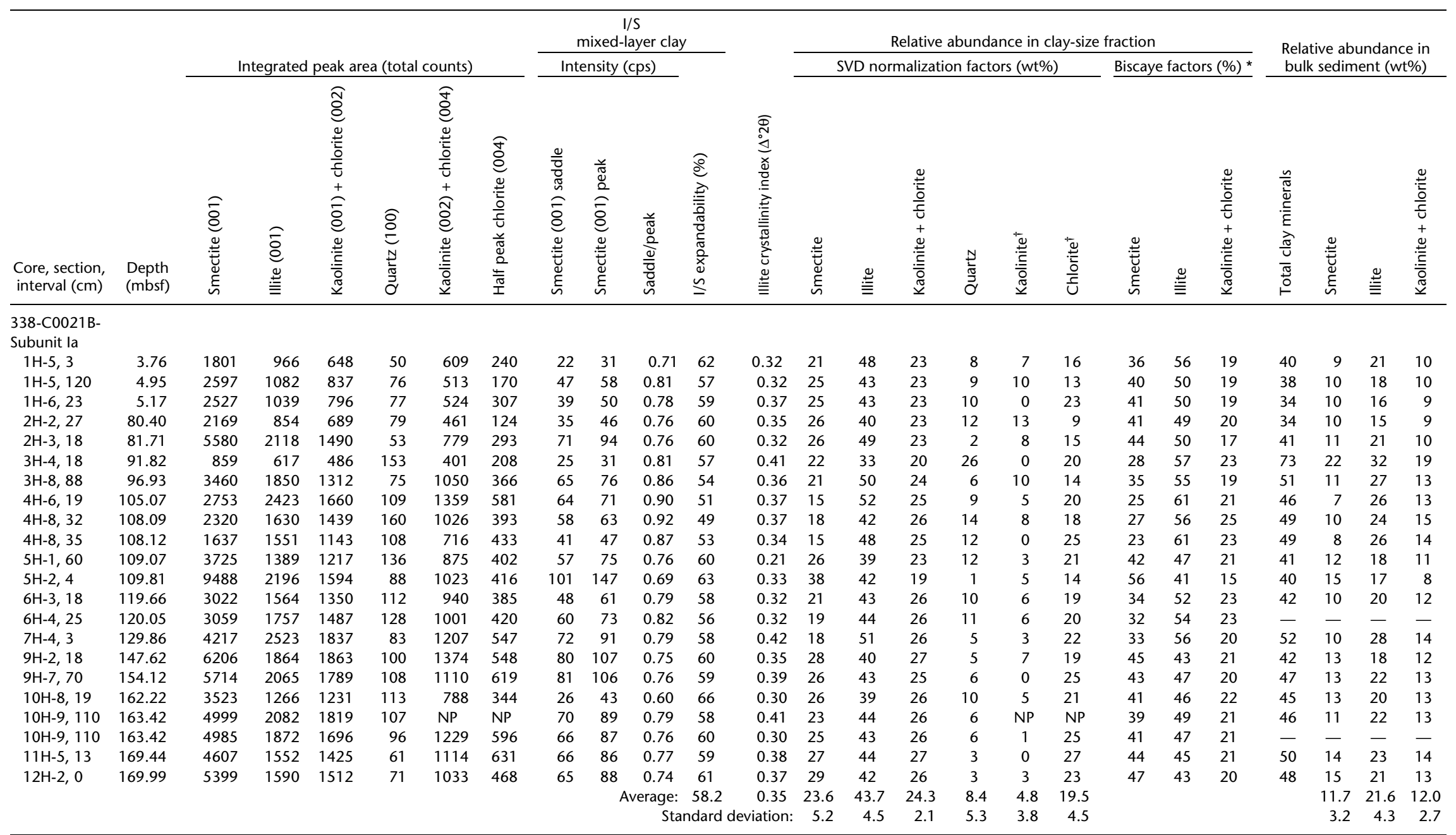

* = Biscaye peak area weighting factors are $1 \times$ smectite (001), $4 \times$ illite (001), and $2 \times$ chlorite (002) + kaolinite (001). $\dagger=$ Proportions of kaolinite and chlorite use the ratio from Guo and Under-

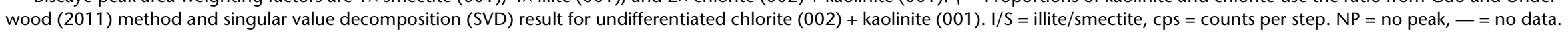

